\title{
The ConTent ANALYsis OF TV COMMERCIALS: STATISTICAL APPROACH
}

\author{
SIMICEVIC, V. \& RACIC, I.
}

Abstract: The purpose of this study is to present media advertising situation in a transitional environment. This paper is focused to the theoretical and methodological basis for research the influence of television advertising and statistical analysis of the $T V$ commercial's content on the Croatian television programs. The new original empirics survey research was conducted at the random sample, including both, public and commercial television models, in order to analyse TV commercials, as a form of modern economic promoting component. The paper put special emphasis on significant differences of the commercials distribution in prime time, between these two television models.

Key words: statistical analysis, advertising research techniques, TV commercials content, prime time, television models
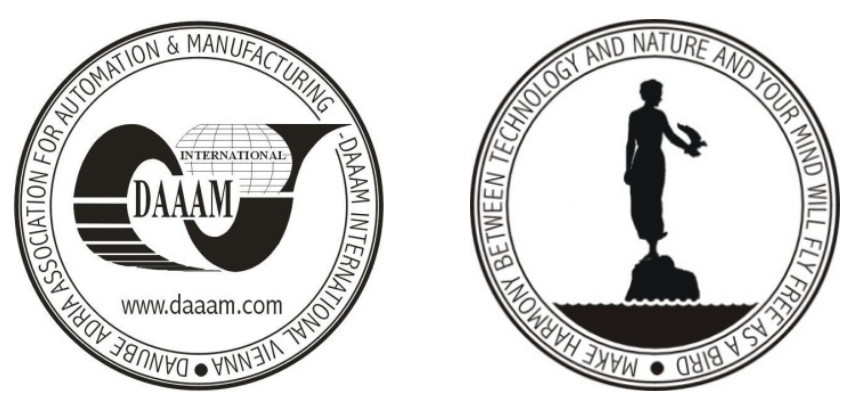

Authors' data: Prof. PhD. Simicevic, V[anja]; Racic, I[figenija], Center for Croatian Studies, University of Zagreb, Picmanova 2, 10010, Zagreb, HR, vanja.simicevic@zg.t-com.hr, ifigenija@gmail.com

This Publication has to be referred as: Simicevic, V[anja] \& Racic, I[figenija] (2008). The Content Analysis of TV Commercials: Statistical Approach, Chapter 62 in DAAAM International Scientific Book 2008, pp. 773-780, B. Katalinic (Ed.), Published by DAAAM International, ISBN 978-3-901509-66-7, ISSN 1726-9687, Vienna, Austria

DOI: $10.2507 /$ daaam.scibook.2008.62 